\title{
Urinary iodine excretion among thyroid peroxidase antibody positive pregnant women: a comparative study
}

\author{
O Sultana ${ }^{1}$, D Hussain ${ }^{2}$, Z Rahman ${ }^{3}$, N Jahan ${ }^{4}$, N Sultana ${ }^{5}$
}

\begin{abstract}
Urinary iodine excretion increases during pregnancy. Presence of thyroid peroxidase antibody (TPO-Ab) accelerates this excretion rate. The objectives of the study was to observe the relation between TPO-Ab and urinary excretion of iodine in normal pregnant women during 1st trimester. This case-control study was carried out in the Department of Physiology, Sir Salimullah Medical College from $1^{\text {st }}$ January to $31^{\text {st }}$ December 2011 . A total number of 120 subjects were included in the study and divided into control group (Group A) and study group (Group B). Group A consisted of 60 healthy non-pregnant women aged between 20 to 35 years. Group B consisted of 60 normal pregnant women of same age range. Group B was further subdivided into Group B1 and Group B2 according to the level of TPO-Ab. Group B1 consisted of 11 TPO-Ab positive pregnant women and Group B2 consisted of 49 TPO-Ab negative pregnant women. Group A was selected from personal contacts and Group B from Out Patient Department of Obstetrics and Gynecology of Sir Salimullah Medical College and Mitford Hospital. For assessment of iodine excretion, urinary iodine concentration, serum TPO-Ab and HCG of all pregnant women was measured by Spectrophotometric method, Microparticle Enzyme Immunoassay and EnzymeLinked Immunosorbent Assay, respectively. In this study, urinary iodine was significantly ( $p<$ $0.001)$ higher in normal pregnant women during $1^{\text {st }}$ trimester in comparison to those of nonpregnant women. Urinary iodine concentration was significantly $(p<0.001)$ higher in TPO-Ab positive pregnant women in comparison to those of TPO-Ab negative. Again, urinary iodine concentration showed significant $(p<0.001)$ positive correlation with that of TPO-Ab. Urinary iodine excretion increased in TPO-Ab positive normal pregnant women during $1^{\text {st }}$ trimester. So, iodine supply should be increased during pregnancy and screening for TPO-Ab should be done routinely during pregnancy.
\end{abstract}

Key words: Urinary iodine, thyroid peroxidase antibody, pregnancy, iodine, trimester.

Introduction

Enormous physiological and biochemical changes including hormonal changes, increase metabolic demand, nutritional requirements, increase urinary clearance, etc take place during pregnancy to meet the demand of the developing fetus. ${ }^{1}$ lodine is an essential micronutrient required for the synthesis of thyroid hormone which causes development of fetal CNS. ${ }^{2}$ So, deficiency of iodine results in mental retardation and stunted growth of the child. ${ }^{3}$ The glomerular filtration rate (GFR) also increases in pregnancy, increasing renal iodide clearance and decreasing the circulatory pool of plasma iodine. ${ }^{4}$ So, an assurance of iodine sufficiency is especially important in pregnancy when maternal thyroid function normally increases by about $50 \% .^{5}$

1. O Sultana MBBS, MPhil, Assistant Professor of of Physiology, Gazi Medical College, Khulna

2. D Hussain MBBS, MPhil, Assistant Professor of of Physiology, Kumudini Women's Medical college, Mirzapur

3. Z Rahman MBBS, MPhil, Associate Professor of Biochemistry, Khulna Medical College, Khulna

4. N Jahan MBBs, MPhil, Professor and Head, Department of Physiology, Sir Salimullah Medical College, Dhaka

5. N Sultana MBBS, MPhil, Associate Professor of Physiology, Sir Salimullah Medical College, Dhaka 
Thyroid peroxidase enzyme is a key enzyme in the formation of thyroid hormone, a major auto-antigen in thyroid disease. Presence of antibody against this enzyme (TPO-Ab) in euthyroid subject can be used to identify subjects with increased risk of hypothyroidism. ${ }^{6}$ Thyroid peroxidase antibody titer of $12 \mathrm{IU} / \mathrm{ml}$ or more is regarded as positive. ${ }^{7}$ This positivity usually alter the thyroid function and may lead to obstetrical complication and negative pregnancy outcome like miscarriage, prematurity, maternal post partum thyroiditis and depression. ${ }^{8}$ The rate of thyroid peroxidase positivity is variable in different countries. It is about $11.2 \%$ in Pakistani, $11.7 \%$ in Italian, $12.4 \%$ in USA and $5.4 \%$ among Brazilian pregnant women. ${ }^{9-12}$ According to World Health Organization and the International Council for Control of lodine Deficiency Disorders, determination of urinary iodine concentration is the key indicator of iodine status in the body as about $90 \%$ of iodine is eventually excreted in urine due to increased GFR in pregnancy. ${ }^{13}$

The aim of the study was to observe the relation between TPO-Ab and urinary excretion of iodine in normal pregnant women during $1^{\text {st }}$ trimester.

\section{Materials and Method}

This cross sectional case control study was carried out in the Department of Physiology, Sir Salimullah Medical College from1st January to 31st December 2011. A total number of 120 subjects were included in the study and divided into control group (Group A) and study group (Group B). Group A consisted of 60 healthy non-pregnant women aged between 20 to 35 years. Group B consisted of 60 normal pregnant women of same age range. Group B was further subdivided into Group B1 and Group B2 according to the level of TPO-Ab. Group B1 consisted of 11 TPO-Ab positive pregnant women and Group B2 consisted of 49 TPO-Ab negative pregnant women. Group A was selected from personal contacts and Group B from Out Patient Department of Obstetrics and Gynecology of Sir Salimullah Medical College and Mitford Hospital.

For assessment of iodine excretion, urinary iodine concentration, serum
TPO-Ab and human chorionic gonadotropin (hCG) of all pregnant women was measured by Spectrophotometric method, Microparticle Enzyme Immunoassay and Enzyme-Linked Immunosorbent Assay, respectively. Statistical analysis was done by SPSS software. Statistical significance was considered when $p<0.05$.

\section{Results}

Urinary iodine concentration and TPO-Ab in both pregnant and non-pregnant women groups are shown in Table 1. The urinary iodine and serum TPO-Ab were significantly higher in pregnant women in comparison to those of non-pregnant women $(p<0.001$ and $p<0.01$, respectively). The number of TPO-Ab positive pregnant women (group B1) was 11 (18\%), whereas 49 (82\%) pregnant women (group B2) were TPO-Ab negative and the serum TPO-Ab was significantly higher in group B1 in comparison to those of group B2 $(p<0.001)$ (Table 2$)$.

The mean serum hCG level was slightly higher in group B1 in comparison to group B2 but the difference was not statistically significant. In contrast, urinary iodine concentration was significantly higher in group B1 comparison to those of group B2 ( $p$ $<0.001$ ) (Table 3).

There was a positive correlation between urinary iodine concentration and TPO-Ab among normal pregnant women during 1st trimester and the relationship was statistically significant $(r=0.520, p<0.001)$ (Fig. 1).

\section{Discussion}

In the present study both urinary iodine concentration and TPO-Ab were significantly higher in normal pregnant women during $1^{\text {st }}$ trimester in comparison to that of non pregnant women. Similar findings were observed by some researchers. ${ }^{14}$ The rate of TPO-Ab positivity was among $18 \%$ pregnant women and the finding was different in other countries. ${ }^{15}$ Urinary iodine concentration was significantly higher in TPO-Ab positive pregnant women during $1^{\text {st }}$ trimester in comparison to that of TPO-Ab negative pregnant women. These finding is in consistent with the findings of some researchers. ${ }^{16}$ In this study pearson's correlation test was performed to observe the relation of urinary iodine concentration with TPO-Ab. Urinary iodine positively and significantly correlated 
Table 1. Urinary iodine concentration and serum thyroid peroxidase antibody (TPO$A b)$ among both pregnant and non-pregnant women groups, $n=120$

\begin{tabular}{lccc}
\hline Groups & $\mathbf{n}$ & $\begin{array}{c}\text { Urinary iodine } \\
(\boldsymbol{\mu g} / \mathrm{L})\end{array}$ & $\begin{array}{c}\text { TPO -Ab } \\
(\mathrm{IU} / \mathrm{ml})\end{array}$ \\
\hline $\mathrm{A}$ & 60 & $171.58 \pm 30.39$ & $4.36 \pm 2.26$ \\
& & $(101-218)$ & $(1.2-10.0)$ \\
$\mathrm{B}$ & 60 & $218.45 \pm 41.94^{\star \star \star}$ & $6.50 \pm 4.23^{\star \star}$ \\
& & $(101-300)$ & $(2.1-16.6)$ \\
\hline
\end{tabular}

Data are expressed as Mean \pm SD (Range). n, number of subjects. Group A, Apparently healthy non-pregnant women (Control group); Group B, Normal pregnant women during $1^{\text {st }}$ trimester (Study group). ${ }^{* \star *}: p<0.001,{ }^{* \star}: p<0.01$ by unpaired Student $t$-test.

Table 2. Thyroid peroxidase antibody (TPO-Ab) among pregnant women during $1^{\text {st }}$ trimester, $\mathrm{n}=60$

\begin{tabular}{lcc}
\hline Groups & $\mathbf{n}$ & $\begin{array}{c}\text { TPO }-\mathrm{Ab} \\
(\mathrm{IU} / \mathrm{ml})\end{array}$ \\
\hline TPO-Ab positive, B1 & 11 & $\begin{array}{l}14.15 \pm 1.49^{\star \star \star} \\
(12.0-16.6)\end{array}$ \\
TPO-Ab negative, B2 & 49 & $4.78 \pm 2.25$ \\
& & $(2.1-10.0)$ \\
\hline
\end{tabular}

Data are expressed as Mean \pm SD (Range). $\mathrm{n}=$ number; Group B1: TPO-Ab positive (TPO-Ab $\geq 12 \mathrm{IU} / \mathrm{ml}$ ); Group B2: TPO-Ab negative (TPO-Ab $<12 \mathrm{IU} / \mathrm{ml}) .{ }^{* * *}: p<$ 0.001 by unpaired Student $t$-test.

Table 3. Urinary iodine concentration among thyroid peroxidase antibody (TPO-Ab) positive and negative pregnant women during $1^{\text {st }}$ trimester, $\mathrm{n}=60$

\begin{tabular}{lcc}
\hline Groups & $\mathbf{n}$ & $\begin{array}{c}\text { Urinary iodine } \\
(\boldsymbol{\mu} \mathbf{g} / \mathbf{L})\end{array}$ \\
\hline TPO-Ab positive, B1 & 11 & $262.09 \pm 31.99^{* \star *}$ \\
& & $(209-300)$ \\
TPO-Ab negative, B2 & 49 & $208.65-37.61$ \\
& & $(101-300)$ \\
\hline
\end{tabular}

Data are expressed as Mean \pm SD (Range). n, number of subjects. Group B1, TPO-Ab positive pregnant women; Group B2, TPO-Ab negative pregnant women. ${ }^{* * *}: p<0.001$ by unpaired Student $t$-test.

with TPO-Ab. A group of researchers suggested that growing fetus release enough antigen to stimulate the maternal immune system which subsequently produce thyroid peroxidase antibodies. ${ }^{17}$

It have been suggested by some researchers that during normal pregnancy, GFR increases within the $1^{\text {st }}$ month of conception, making a peak by the end of the $1^{\text {st }}$ trimester at approximately $40-50 \%$ above that of the non-pregnant levels. ${ }^{18}$

According to several other researchers, increased renal blood flow and increased renal clearance of iodine are responsible for increased urinary iodine concentration during $1^{\text {st }}$ trimester. ${ }^{19}$ TPO-Ab has stimulatory effect on GFR and renal clearance of iodine which explains the positive correlation between 


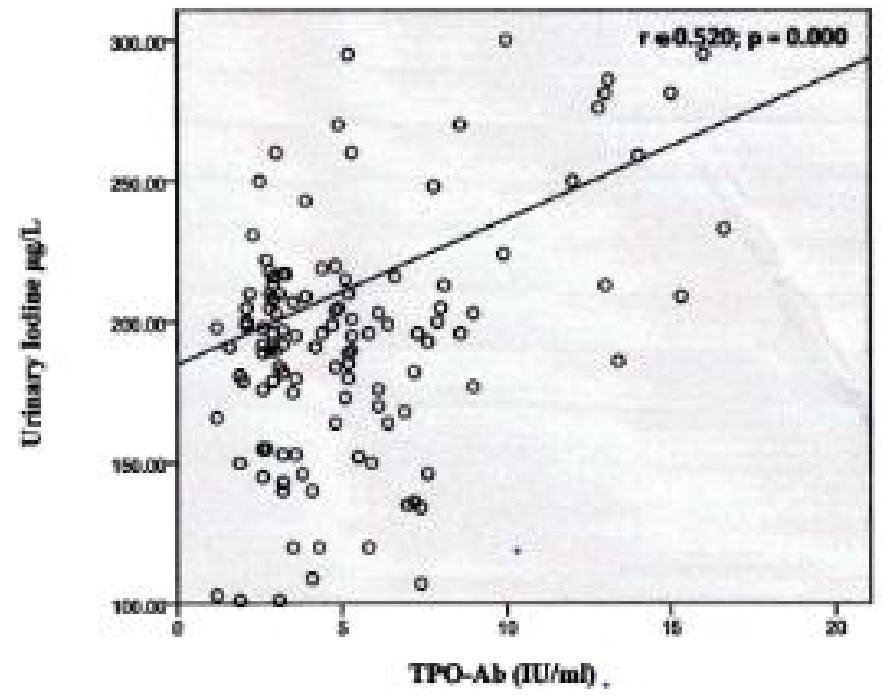

Fig. 1. Correlation of urinary iodine concentration with thyroid peroxidase antibody (TPO-Ab) in normal pregnant women during 1 st trimester, $(n=60)$. Pearson correlation test revealed $\mathbf{r}=0.520, p<0.001$.

TPO-Ab and urinary iodine concentration. ${ }^{20}$ Therefore, the positive correlation between between TPO-Ab and urinary iodine concentration in this study indicated increased loss of iodine in TPO-Ab positive pregnant women and emphasis should be given on increased supply of iodine to this group of women. Further study is needed to examine the benefits of iodine supplementation on neonatal and childhood neurodevelopment in iodine deficient pregnant women.

\section{Conclusion}

The results of the present study, positive correlation between between TPO-Ab and urinary iodine concentration, indicates increased loss of iodine in TPO-Ab positive pregnant women and therefore, emphasis should be given on increased supply of iodine to this group of women.

\section{Limitations}

i) Thyroid status of pregnant women was not assessed in this study.

ii) Pregnancy TPO-Ab status of the pregnant women was not assessed in this study.

\section{References}

1. Glioner D. Thyroid regulation and dysfunction in the pregnant patient. 2010. (www.thyroidmanager.org; accessed on August 15, 2015).
2. Dunn JT. "What happening to our iodine". $\mathrm{J}$ Clin Endocrinol Metab 1998;43(10): 3398-400.

3. Negro R, Schwartz A, Gismondi R, Tinnelli A, Stagenaro GA. Thyroid peroxidase positivity in the first trimester of pregnancy is associated with negative pregnancy outcome. J Clin Endocrinol Metab 2011;96(6):920-4.

4. Dafnis E, Sabatini S. The effect of pregnancy on renal function: physiology and pathophysiology. Am J Med Sci 1992;303(3):184-205.

5. Angela ML, Elizabeth NP. Thyroid disease in pregnancy. US Endocrinology 2008; 4(1):100-3.

6. Prummel MF, Wiersinga WM. Thyroid peroxidase autoantibodies in euthyroid subjects. Best Pract Res Clin Endocrinol Metab 2005;19(1):1-15.

7. Emmersion $\mathrm{CH}$. Thyroid disease during and after pregnancy. In: Braverman LE and Utigo RD (eds.).The Thyroid. Lippincott, Philadelphia, 1991; 6th ed, pp.1263-79.

8. Johannes L, Kujipens L, Vador HA, et al. Thyroid peroxidase antibodies during gestation are marker for subsequent postpartum depression. Eur J Endocrinol 2001;45:573-84.

9. Ghafoor F, Mansoor M, Malek T, et al. 
Role of thyroid peroxidase antibodies in the outcome of of pregnancy. J Coll Physicians Surg Pak 2006;16(7):468-71.

10. Negro R, Gianni F, Tiziana M, Antonio P, David D, Haslinda $H$. Levothyroxine treatment in euthyroid pregnant women with autoimmune thyroid disease: effects on obstetrical complications. J Clin Endocrinol Metab 2006;91(7):2587-91.

11. Pearce EN, Oken E, Gilman MW, et al. Association of first trimester thyroid test values with thyroid peroxidase antibody status, smoking and multivitamine use. Endocr Pract 2008;13(14):33-9.

12. Sieiro NL,Medina C, Micmacher E, et al. Influence of thyroid autoimmunity and maternal age on the risk of miscarriage. Am J Reprod Immunol 2004;52(5):312-6.

13. Stilwell G, Reynolds JP, Parameswaran V, Blizzard L, Greenway TM, Burgess JR. The influence of gestational stage on urinary iodine excretion in pregnancy. $\mathrm{J}$ Clin Endocrinol 2008;93:1737-42.

14. Zarghami N, Noubar RM, Kosrowbeyi. Thyroid hormone status during pregnancy in normal Iranian women. Indian $\mathrm{J}$ Clin Biochem 2005;20:182-5.
15. Aguayo A, Grau G, Aniel-Quiroga A, et al. Urinary iodine and thyroid function in a population of healthy pregnant women in the North of Spain. J Trace Elem Med Biol 2013;27(4):302-6.

16. Jaiswal N, Melse-Boonstra A, Thomas T, et al. High prevalence of maternal hypothyroidism despite adequate iodine status in Indian pregnant women in the first trimester. Thyroid 2014;24(9): 1419-29.

17. Galofre JC, Daves TF. Autoimmune thyroid disease in pregnancy: a review. J Womens Health (Larchmt) 2009;18(11): 1847-56.

18. Ardawi MSM, Nasrat HA, Mustafa BE. Urinary iodine excretion and maternal thyroid function during pregnancy and postpartum. Saudi Med J 2002; 23(4):413-422.

19. Mansourian AR. Thyroid function test during first trimester of pregnancy: a review of literature. Pak J Biol Sci 2010;13(14):664-73.

20. Lazarus JH, Premawardhana LDKE. Screening for thyroid disease in pregnancy. $\mathrm{J}$ Clin Pathol 2005;58:449-52

\section{Suggestion for citation of the above:}

Sultana O, Hussain D, Rahman Z, Jahan N, Sultana N. Urinary iodine excretion among thyroid peroxidase antibody positive pregnant women: a comparative study. Mediscope 2016;3(1):28-32. 